Development of the measuring system for ion acoustic wave in the plasma

\title{
プラズマ中のイオン音波測定システムの開発
}

Atsushi NISHINO and Akira TONEGAWA,

Department of Physics, Society of Science, Tokai University, 1117 Kitakaname,

Hiratsuka, Kanagawa, 259-12 Japan

TEL:81-463-58-1211(EXT.3684) FAX:81-463-58-1218

Kazuo TAKAYAMA

Institute of Research \& Development, Tokai University, 1117 Kitakaname, Hiratsuka, Kanagawa, 259-12 Japan

TEL : 81-0463-58-1211 (Ext5300)

( Accepted for publication 16 November 1995 )

We developed the measuring system for the ion acoustic wave in the plasma. The phase velocity of the ion acoustic wave is obtained by phase delay between the excitation signals and the received signals in the glow discharge with parallel electrodes.

Keywords : plasma, ion acoustic wave, HPVee, computer system,

\section{I . INTRODUCTION}

プラズマ中における波動の特性を調べる上で重 要なことは、どのような時間的変動が、空間的に どう伝搬していくかということである。本研究の 目的は、プラズマ中の波動をコンピュータにより 測定するシステムを開発することである。ここで は特に、磁場のない静電プラズマ波の例としてイ オン音波に着目した。イオン音波はイオンの振動 が重要になる低周波の縦波であり、比較的容易に 波を励起させることができる。実験ではグロ一放 電のプラズマ中にイオン音波を励起させ、その位 相差を測定し、分散関係式によって求めた速度と
比較した。

II. THEORY AND EXPERIMENTAL SETUP

イオン音波はクーロンカと電子の熱運動によっ て振動が伝わる。つまり、電場を媒介として音波 が起きるということで、質量の大きなイオンの運 動が関係しているため低周波の振動である。'また, この振動を考える上で重要な式を以下に示す。

·磁場のないときのイオン流体の方程式 ・イオンの密度の摂動（Boltzmann 方程式） ・イオンの連続の方程式（線形化）

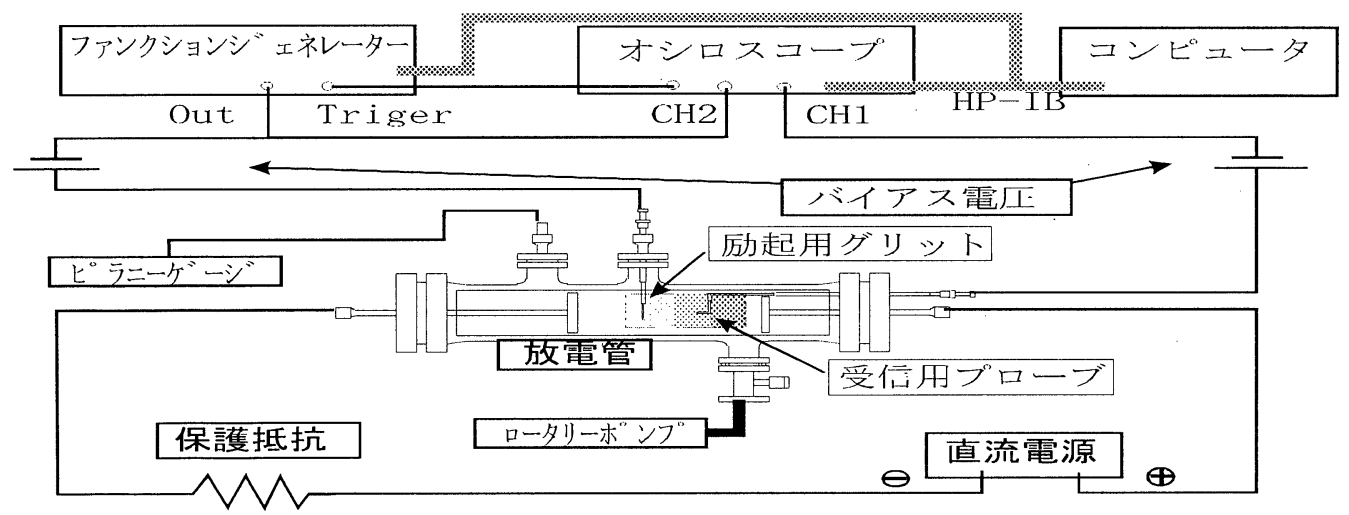

FIG. 1. Ion acoustic wave measures system. 
以上の 3 つの式より分散関係式を求めると、

$$
\frac{\omega}{k}=\left(\frac{k_{B} T_{e}+\gamma_{i} k_{B} T_{i}}{M}\right)^{1 / 2} \equiv v_{S}
$$

$T_{e}=$ 電子温度、 $T_{i}=$ イオン温度、 $M=$ イオン質量、 $\omega=$ 角周波数、 $k=$ 伝搬定数、 $k_{B}=$ ボルツマン定数 となり、これがイオン音波の分散関形式である。 また、グロ一放電など $\mathrm{T}_{\mathrm{e}}$ が T , より非常に大きい ときは、音波の伝播速度は次のようになる。

$$
v_{S}=\sqrt{k_{B} T_{e} / M}
$$

測定するプラズマの条件は、 $\mathrm{Ar}$ (アルゴン) を 用いて 0. 2Torr にし、放電電流 0.1A、放電電圧 $419 \mathrm{~V}$ とした。測定の方法は Fig.1 に示すように、励 起用グリットに、10kHz の Sinカーブを送り、励起 用グリットと受信用プローブの間隔を変化させ、 励起波と受信波の位相のずれとグリット間隔との

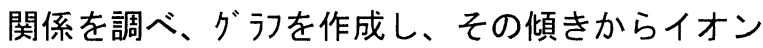
音波の速度を求めた。

\section{FLOW CHART (HP Vee)}

この実験で重要なのは、コンピュータによる測 定システムの開発である。これは、コンピュータ 上で実験装置のオブジェクトを配置し、それらを 結ぶことにより、簡単に測定ができるということ や、コンピュータ上の実験装置の数値等を変更す ることによって、リモート操作できるということ が利点となる。

HP Vee プログラムの流れは Fig.2 に示すよj に、オブジェクトFrequencyに測定周波数を入力 しオブジェクトTimebaseにオシロスコープのタイ ムベースを書き込む。コマンドStart でプログラ ムが実行されフアンクションジ ェ礼ターから Sinカーブが出 る。そして、オシロスコープに波形を表示し、Data をセーブする。

\section{EXPERIMENTAL RESULTS}

励起波 $10 \mathrm{kHz}$ で、グリットとプローブの間隔を $20 \mathrm{~mm}$ から $90 \mathrm{~mm}$ まで $10 \mathrm{~mm}$ 間隔で変更し、位相差を 測定した。その結果のグラフをFigure 3, Fig.4 に示す。Figure 4 の直線の傾きから、イオン音波

\begin{tabular}{|c|c|c|}
\hline \multicolumn{3}{|c|}{ Stant } \\
\hline Frequeno & フファンクションジ & -29- \\
\hline Timebase & $\frac{1}{\text { Delay }}$ & 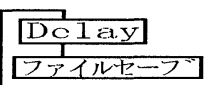 \\
\hline
\end{tabular}
速度が与えられる。傾きからのイオン音波速度は

FIG. 2. HP Vee program.

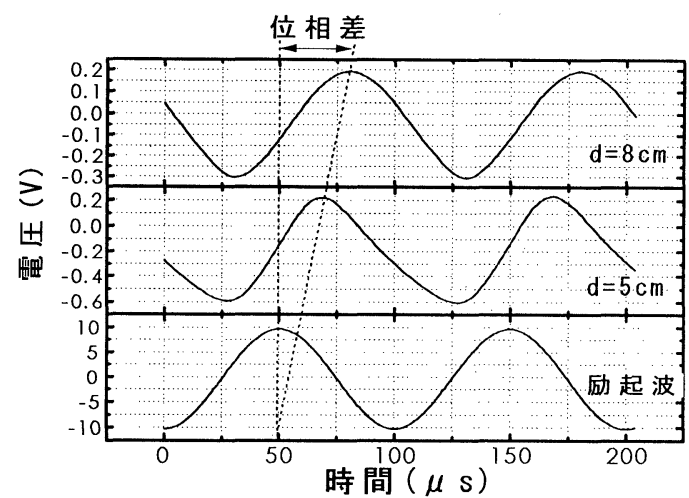

FIG.3. Oscilloscope showing the excitation signals and the received signal in Argon. $d$ is the distance between the grids.

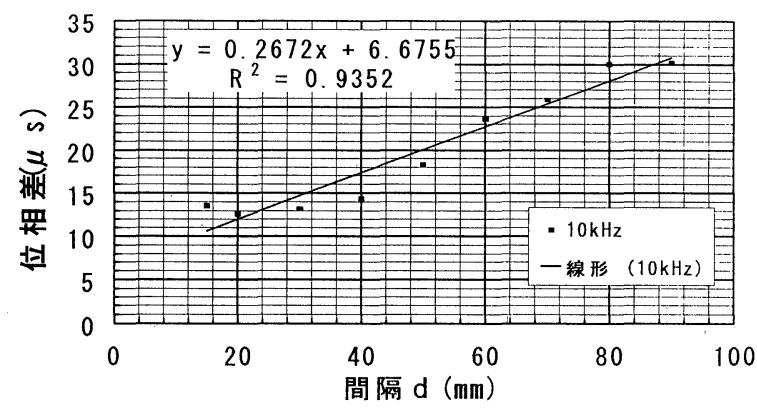

FIG. 4. Phase delay of the ion waves as a function of the separation between the grids in the argon plasma.

$v_{S}=3.7425(\mathrm{~mm} / \mu \mathrm{s})=3.7425 \times 10^{3}(\mathrm{~m} / \mathrm{s})$ となり、 分散関係式によるイオン音波の速度は $v_{S}=2.5012 \times 10^{3}(\mathrm{~m} / \mathrm{s})$ となった。

\section{CONCLUSION}

測定結果より、システム作動を確認する事がで きた。ここで、コンピュータ（HP Vee) による測 定の利点は、測定時間が短縮されるため放電管に よるプラズマ実験など、測定条件を長い時間維持 することが困難な時、より多くのデータを得るこ とが可能になる。また、オシロスコープ上に表示 された波形などを簡単に保存できるため、測定後 の処理が容易になった。装置のオブジェクトをマ ウスによりコンピュータ上に配置し、結ぶことに よって誰にでも簡単に測定ができるようになる。

\section{REFERENCES}

'A. Y. Wong, R. W. Mote ly and N. D'Ange lo Phys. Rev 133, A 436 (1964)

'95 SAS Intelligent Symposium 